\title{
COMPARATIVE INTRAOCULAR PRESSURE REDUCTION EFFICACY OF LATANOPROST AND TIMOLOL MELEATE IN OPEN ANGLE GLAUCOMA AND OCULAR HYPERTENSIVE PATIENT
}

\author{
BY \\ *OSUDE-UZODIKE, E. B. AND ANTHONY, J. I. \\ DEPARTMENT OF OPTOMETRY, \\ ABIA STATE UNIVERSITY \\ UTURU, ABIA STATE, NIGERIA \\ Email:ebeluzo@yahoo.com \\ *Corresponding author
}

\section{ABSTRACT}

Latanoprost $0.005 \%$ and timolol maleate $0.5 \%$ were compared in a five week randomized study using 20 patients with primary open angle glaucoma and ocular hypertension. 50\% of the patients received latanoprost while the other half was treated with timolol ${ }^{\circledR}$. The two drugs were compared with regard to their efficacy in lowering intraocular pressure and tolerability. Latanoprost effected an average reduction of $12.4 \pm 4.3 \mathrm{mmHg}(35 \%)$ in $\mathrm{OD}, 12.4 \pm 2.4 \mathrm{mmHg}(35 \%)$ in $\mathrm{OS}$ and $12.4 \pm 2.9 \mathrm{mmHg}(35 \%)$ in OU. Timolol $^{\circledast}$, on the other hand, effected a reduction of $8.5 \pm 3.2 \mathrm{mmHg}(27.5 \%)$ in OD, $9.1 \pm 3.3 \mathrm{mmHg}(28.6 \%)$ in OS and $8.8 \pm 2.3 \mathrm{mmHg}(28.1 \%)$ in OU. Student's T-test analysis showed the reductions to be significant $(\mathrm{P}<0.05)$ in the two group. However, latanoprost showed $80 \%$ tolerability while timolol ${ }^{\oplus}$ showed $30 \%$ tolerability.

KEYWORDS: Latanoprost, Timolol maleate, Intraocular pressure, Open angle glaucoma, Prostaglandin.

\section{INTRODUCTION}

In recent times, preventable blindness resulting from glaucoma has become a cause for concern globally with more preponderance in subSaharan Africa. Glaucoma is a chronic eye disease, which has beaten the numerous untiring efforts of researchers to unravel its etiology and subsequently improve its prognosis.

Continuous concerted efforts are being made to curb this trend. This has resulted in the introduction of countless anti-glaucomatous drugs in the market today. Presently, no known cure has implicated with the visual complication of glaucoma

The comparative anti-glaucomatous properties of timolol maleate and latanoprost, which are nonselective -adrenergic blocking agent and prostaglandin F2a-analogue respectively, will be studied. The two drugs have different modes of action in improving aqueous outflow. Timolol ${ }^{\circledR}$ treats glaucoma by decreasing aqueous secretion from the uveoscleral outflow of aqueous humor.

Timolol $^{\circledR}$ ophthalmic sterile solution is commercially available in concentrations of $0.25 \%$ and $0.5 \%$. The maximum IOP reducing effect of Timolo ${ }^{\circledR}$ is peaked at 2 hours after instillation and lasts for 24 hours $^{2}$ The optimum frequency of administration in most cases is twice daily although once a day regimen has been shown to be effective $^{3 .}$ Individuals with darker irides appear to require higher concentrations ${ }^{4}$ It is widely used in chronic open angle glaucoma (OAG) and secondary glaucoma. The principal physiologic action of Timolol $^{\circledR}$ is to competitively block $\mathrm{\sigma}$ adrenergic receptors within the myocardium $\left(\mathrm{b}_{1}-\right.$ receptors) and with bronchial and vascular smooth muscle $\left(\bar{b}_{1}-\text { receptors }\right)^{6}$. Timolol ${ }^{\oplus}$ continues to be effective after many months of therapy but a tendency for slow rise of IOP has been observed, it is termed ñlong term driftò. It is uncertain whether this ñdriftòis due to a loss of efficacy of Timolol ${ }^{\circledR}$, worsening of glaucoma or both.

Latanoprost is an isopropyl ester of prostaglandin F2-analogue, and is metabolized in the liver ${ }^{8}$. Xalantan ${ }^{\circledast}$ is a lipophilic, esterified prodrug which becomes biologically active when it undergoes enzyme hydrolysis in the cornea ${ }^{9}$ The Product of hydrolysis is the acid form of latanoprost, which passes into the aqueous humor and is carried to the ciliary muscle ${ }^{9}$. Prostaglandin receptors are believed to be present in ciliary muscle and its analogue acts on these receptors increasing the outflow of aqueous. The drainage capacity of uveoscleral route is high; drugs enhancing the uveoscleral outflow will achieve a 
significant IOP lowering effects $^{10}$. Xalantan ${ }^{\circledR}$ sterile ophthalmic solution contains $0.005 \%$ latanoprost and the topical regimen is once daily.

\section{MATERIALS AND METHODS}

Out patients visiting Abia State University, Optometry clinic for the first time who have been diagnosed to have open angle glaucoma (OAG) or ocular hypertension with IOP $>21 \mathrm{mmHg}$ were used for the study. Oral consent was sort and obtained from the patients.

The volunteers where within ages 23-70 years and body weight of $50-75 \mathrm{~kg}$ since they are old enough to understand and comply with instructions. They had no systemic disease or other visual problems, not on any systemic or ocular medication, and no history of ocular surgery.

20 volunteers (10males and 10 females) were then selected for the study based on the above criteria. The research subjects were divided into two groups of 10. Each group had 5 males and 5 females. Their initial IOP were measured (using Schiotz indentation tonometer) and recorded. This served as the control value before commencement of therapy. Hence each patient served as his/her own control.

Group a received timolol meleate ophthalmic solution $(0.5 \%)$ applied one drop into the lower fornix of each eye on 12-hourly interval. Group B was given latanoprost ophthalmic solution $(0.005 \%)$ applied one drop into the lower fornix of each eye once daily (in the evenings). The followup IOP measurements were carried out on weekly basis between 10.00 hours and 11.00 hours to take into consideration the diurnal variations of IOP. The therapy lasted for 5 weeks.

The data obtained was statistically analyzed using table, percentages and student's T- test. The rate at which the drugs (Latanoprost and Timolol meleate ophthalmic solutions applied at the specified doses) reduced IOP was calculated using the formula:

\section{$\Sigma / \mathrm{MC} . \mathrm{IOP} /$}

Time in days

Where $\Sigma / \mathrm{MC} . \mathrm{IOP} /$ is the induced mean change in IOP. Percentage tolerability was also determined with the formula:

$\%=\underline{\text { n-(no. of patients that experienced adverse effects) }}$ $\mathrm{N}$ (total no. of patients in the group)

Timolol $^{\circledR}$ sterile ophthalmic solution used was by Havid SDN. HHD, Malaysia, Xalatan ${ }^{\circledR} 0.005 \%$ sterile ophthalmic solution used was by Pharmacia and Upjohn, Belgium.

\section{RESULTS}

Data obtained from the two groups of volunteers, those receiving latanoprost opththalmic solution and those receiving timolol meleate ophthalmic solution regimens were statistically analyzed. The results showed that latanoprost effected a mean reduction of $12.4 \pm 4.3 \mathrm{mmHg}$ (from baseline IOP of $35.2 \pm 4.3$ $\mathrm{mmHg}$ to induced IOP of $22.9 \pm 4.3 \mathrm{mmHg}$ ) in OD and OS; and mean reduction of $12.4 \pm 2.9 \mathrm{mmHg}$ (from baseline of $34.5 \pm 2.9 \mathrm{mmHg}$ to induced IOP of $22.6 \pm 2.9 \mathrm{mmHg}$ ) in OU. Timolol ${ }^{\circledR}$ effected a mean reduction of $8.5 \pm 3.2 \mathrm{mmHg}$ (from $30.1 \pm 3.2$ $\mathrm{mmHg}$ to $21.6 \pm 3.2 \mathrm{mmHg}$ ) in OD; $9.1 \pm 3.3 \mathrm{mmHg}$ (from $30.7 \pm 3.3$ to $21.6 \pm 3.3$ ) in OS; and $8.8 \pm 2.3 \mathrm{mmHg}$ (from $30.4 \pm 2.3 \mathrm{mmHg}$ to $21.6 \pm 2.2 \mathrm{mmHg}$ in OU (table 1 ).

The percentage reductions were found to be $34.5 \%, 35.3 \%$ and $34.9 \%$ for OD, OS and OU respectively for latanoprost ophthalmic solution and $27.5 \%, 28.6 \%$ and $28.1 \% \mathrm{OD}, \mathrm{OS}$, and $\mathrm{OU}$ respectively for timolol meleate ophthalmic solution (see table 1). Table 2 showed the weekly reduction in IOP due to the use of the two drugs.

Table 3 showed that ocular complaints noted was discomfort (4 cases) followed by ocular pain and tearing ( 2 cases each). In all, the group placed on timolol meleate therapy had more complaints than those placed on latanoprost therapy. These complaints when converted into tolerability level, latanopprost gave $80 \%$ while timolol meleate gave $30 \%$.

\section{DISCUSSION}

Analysis of the results showed that Xalatan ${ }^{\circledR}$ effected an intraocular pressure (IOP) decrease of $12.4 \pm 4.3 \mathrm{mmHg}$ in OD and OS and $12.4 \pm 2.9 \mathrm{mmHg}$ in OU. The mean percentage decreases in IOP were $34.5 \%, 35.3 \%$ and $34.9 \%$ for OD, OS and OU respectively. Timolol ${ }^{\circledR}$ application resulted in mean IOPdecrease of $8.5 \pm 3.2 \mathrm{mmHg}, 9.1 \pm 3.3 \mathrm{mmHg}$ and $8.8 \pm 2.3 \mathrm{mmHg}$ in $\mathrm{OD}$, OS and OU respectively. The mean percentage deceases were $27.5 \%, 28.6 \%$ and $28.1 \%$ for OD, OS and OU respectively (see table1). Thus, both drugs under study were effective in lowering IOPs of the volunteers. The gradual weekly reductions were also shown in table 2.

Researchers like Melton and Thomas ${ }^{11}$ believed that prostaglandin analogue loosens the intracellular spaces within the face of the ciliary 
body, enabling enhancement of uveoscleral aqueous outflow. They maintained that approximately $10 \%$ of aqueous outflow in humans is via the uveoscleral pathway. Timolol ${ }^{\circledR}$ has been shown to inhibit the ability of neurotransmitters, norepinephrine or other sympathomimetic amines to interact effectively with their receptors thus reducing aqueous production. Some evidence exist which suggests that Timolol $^{\circledR}$ also increases aqueous outflow from anterior chamber ${ }^{12}$. The result above agreed with Soll's ${ }^{3}$ who found an IOP reduction within a range of $18-25 \%$. According to Camras and Watson $^{13}, 30-35 \%$ reduction in IOP is possible with latanoprost or non-selective betablockers such as Timolo ${ }^{\circledR}$.

The rate at which Latanoprost ophthalmic solution (applied on drop daily) reduced IOP in the volunteers was found to be $0.354 \mathrm{mmHg} / \mathrm{day}$. Timolol maleate ophthalmic solution (applied one drop twice daily) reduced IOP in the volunteers at the rate of $0.220 \mathrm{mmHg} /$ day.

The mean IOP decrease was steady throughout the five weeks study period. Statistical analysis using student's T-test showed that the decreases were significant $(\mathrm{P}<0.05)$ in the two groups, hence the IOP reduction effect of latanoprost $(0.005 \%)$ and Timolol meleate $(0.5 \%)$ ophthalmic solutions were statistically significant $(\mathrm{P}<0.05)$. This agreed with the findings of researcher like Warren and Fredrick $^{14,}$ and Camras ${ }^{15}$.

Mild discountfort, itching and tearing were reported to occur immediately after instillation of timolol $^{\circledR}$ and occasionally with latanoprost. In no instance were these complaints sufficiently servere to cause non-compliance to the use of drugs. Tolerability was assessed subjectively. Timolol gave $30 \%$ tolerability while latanoprost gave $80 \%$ tolerability (table 3 ).

In conclusion, $0.005 \%$ latanoprost ophthalmic sterile solution was found to be more effective in IOP reduction and better tolerated by the patients than $0.5 \%$ timolol meleate sterile ophthalmic solution, hence can be used by practitioners as drug of choice for management of open angle glaucoma.

TABLE 1: MEAN VALUES OF EFFECT OF 0.005\% LAT ANOPROST AND $0.5 \%$ TIMOLOL MALEATE ON IOP MEAURESMENT IN BOTH EYE S.

\begin{tabular}{|c|c|c|}
\hline 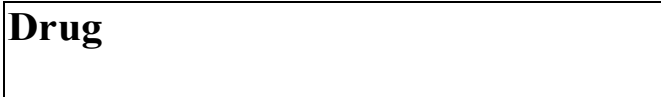 & \begin{tabular}{|l|}
$0.005 \%$ \\
Latanoprost
\end{tabular} & \begin{tabular}{|l|}
$0.5 \%$ \\
Timolol Maleat
\end{tabular} \\
\hline Mean Initial IOP $(\mathrm{mmHg})+$ SEM & $\begin{array}{l}\text { OD } 35.2 \pm 4.3 \\
\text { OS } 34.5 \pm 4.3 \\
\text { OU } 34.5 \pm 2.9\end{array}$ & $\begin{array}{l}30.1 \pm 3.2 \\
30.7 \pm 3.3 \\
30.4 \pm 2.3\end{array}$ \\
\hline Mean Induced IOP $(\mathrm{mmHg})+\mathrm{SEM}$ & $\begin{array}{l}\text { OD } 22.9 \pm 4.3 \\
\text { OS } 22.2 \pm 4.3 \\
\text { OU } 22.6 \pm 2.9\end{array}$ & $\begin{array}{l}21.6 \pm 3.2 \\
21.6 \pm 3.3 \\
21.6 \pm 2.3\end{array}$ \\
\hline Mean IOP Difference $(\mathrm{mmHg})+$ SEM & $\begin{array}{l}\text { OD } 12.4 \pm 4.3 \\
\text { OS } 12.4 \pm 4.3 \\
\text { OU } 12.4 \pm 2.9\end{array}$ & $\begin{array}{l}8.5 \pm 3.2 \\
9.1 \pm 3.3 \\
8.8 \pm 2.3\end{array}$ \\
\hline Mean \% IOP Decease (mmHg) & $\begin{array}{l}\text { OD } 34.5 \\
\text { OS } 35.3 \\
\text { OU } 34.9\end{array}$ & $\begin{array}{l}27.5 \\
28.6 \\
28.1\end{array}$ \\
\hline
\end{tabular}

TABLE 2: THE EFFECTS OF LATANOPROST AND TIMOLOL ON THE IOPS OF THE OD, OS AND OU MONITORED ON WEEKLY BASIS

\begin{tabular}{|l|l|l|l|l|l|l|l|}
\hline Drug & Eye & O Week & $\mathbf{1}^{\text {st }}$ Week & $\mathbf{2}^{\text {nd }}$ Week & $\mathbf{3}^{\text {rd }}$ Week & $\mathbf{4}^{\text {th }}$ Week & $\mathbf{5}^{\text {th }}$ Week \\
\hline $\begin{array}{l}0.005 \% \\
\text { Latanoprost 0.5\% }\end{array}$ & OD & 35.2 & 29.8 & 23.2 & 23.0 & 22.0 & 12.8 \\
Timolol & OD & 30.1 & 25.6 & 23.1 & 21.3 & 19.7 & 18.1 \\
\hline $\begin{array}{l}0.005 \% \\
\text { Latanoprost 05\% } \\
\text { Timolol }\end{array}$ & OS & 34.5 & 29.5 & 29.2 & 23.3 & 19.1 & 11.7 \\
\hline $\begin{array}{l}0.005 \% \\
\text { Latanoprost 05\% } \\
\text { Timolol }\end{array}$ & OU & 30.7 & 25.3 & 23.1 & 21.3 & 20.0 & 16.7 \\
\hline
\end{tabular}


TABLE 3: PERCENTAGE TOLERABILITY

\begin{tabular}{|c|c|c|}
\hline Complaints & $\begin{array}{l}\text { Timolol } \\
(n=10)\end{array}$ & $\begin{array}{l}\text { Latanoprost } \\
(n=10)\end{array}$ \\
\hline Discomfort & 3 & 1 \\
\hline Ocular pain & 1 & 1 \\
\hline Itching & 0 & 0 \\
\hline Tearing & 2 & 0 \\
\hline Photophobia & 0 & 0 \\
\hline \multirow[t]{2}{*}{ Heaviness of Eyes } & 1 & 0 \\
\hline & 7 & 2 \\
\hline
\end{tabular}

\section{R E F E R E N C E S}

1. Katzung, B. G. (1995): Pharmacokinetice properties of Beta-receptor antagonists. Basics and Clinical Pharmacology, $6^{\text {th }}$ Edn. Appleton and Lange, 538pp.

2. Zimmerman, J. J. and Herbert, K. E. (1997): Timolol. Arch. Opthalmol, 95:601-7.

3. Soll, D. B. (1980): Evaluation of Timolol in chronic open angle glaucoma. Arch. Opthalmol, 98:2178-81.

4. Katz, I. M. and Berger, E. I. (1979): Effect of iris pigmentation on response of ocular pressure to timolol. J. Surv. Ophthalmol, 23 (6):395-8.

5. Newell, F. W. (1992): Glaucoma. Ophthalmology - Principles and Concepts. $5^{\text {th }}$ Edn. The CV Mosby Co. London, 559pp.

6. Gerald, M. K. (1991): Timolo Meleate and Betaxolol hydrochloride. $33^{\text {rd }}$ Edn. AHTS Drug information, 2015pp.

7 Boger, W. P.III (1979):Timolol-Short-term escape and long term drift. Am. J. Ophthalmol,11(1): 1239-42.

8. Mills, D. (1997): Latanoprost (Xalatan) product. Monograph Upjohn, 4pp.

9. McClellan, K. (1995): Topical eye preparations optimum use.Curr. Ther, 36:61-6.

10. Patel, S. S. and Spencder, C. M. (1996): Latanooprost $̈$ review of it properties, clinical efficiency and tolerability in the management of primary open angle glaucoma and ocular hypertension. J. Ophthalmol, 103 (1): 898907.

11. Melton and Thomas (2001): Clinical guide to ophthalmic drugs. J. Review Opt, (Suppl): 6-8.

12. Berropsi, R and Leibowitz, H. (982): Timolol. Arch. Ophthalmol, 100 (1): 943-6.

13. Camras, C. R., Wastson, A. A., Stijemshante, J. and the Latanoprost study group (1996): Latanoprost, a prostaglandin analogue for glaucoma therapy ï Efficacy and safety after 1 year of treatment in 198 patients. J. Ophthalmol, 103: 1916-24.

14. Warren, J. and Frederick, A. (1989): Effect of Latanoprost on intraocular pressure following cataract extraction. Br. J. Ophthalmol, 74:41926.

15. Camras, C. B. (1996): Comparison of Latanoprost and timolol in patients with ocular hypertension and glaucoma. J. Ophthalmol, 103(1):138-47. 